\title{
The Advance Experience of Foreign Top-level Think Tanks and its Enlightment to the Construction of Chinese University Think-Tank
}

\author{
Yong Tao ${ }^{1}$, Qiushi $\mathrm{Li}^{1}$, Gang Zhao ${ }^{2}$ and Wen Zhao ${ }^{1}$ \\ ${ }^{1}$ National Laboratory on Aerospace/The Chinese Institute of Aeronautical Engineering Development Strategies, Beihang Univerisy, Beijing, \\ China \\ ${ }^{2}$ School of Mechanical Engineering and Automation, Beihang University, Beijing, China
}

\begin{abstract}
This paper expounds the development course and current situation of foreign top-level Think Tank, and analyzes the important effects of foreign colleges and universities Think Tank in supporting national scientific decision-making and rapid development. It analyzes the development course and advanced experience of top-level Think Tank in America and other countries. The paper summaries the advance experiences, combines with the background and features of Think Tank construction of colleges and universities in China. It puts forward that Chinese colleges and universities Think Tank should aim at the national strategic needs, play the advantages of talents gathering and main innovation force, insist on opening, and set constructing professional colleges and universities Think Tank as the breakthrough point. The think tanks produce strategic consulting research results with high quality. The paper proposes the reference effect of foreign Think Tank on characteristic Think Tank construction of colleges and universities in China and the development strategy recommendations.
\end{abstract}

\section{Introduction}

Think Tank is also called as "Idea Tank". The internationally accepted definition on Think Tank is the public research institution that is composed by experts, combines multi disciplines, gives advice and suggestions for decision maker to deal with social, economic, scientific, military, diplomatic and other aspects issues, then makes investigation, analysis and research on political, economic, social, cultural, military and other policies, so as to provide the best theories, strategies, methods, ideas, etc. it is an important force to influence government's decision-making and promote social development [1].

In order to respond all the challenges faced with by industries, respond the difficult issues during development, we not only need enough courage, but also need enough wisdom, we should agglomerate the wisdom of the whole industry, even all humans, we need the Think Tank with irreplaceable role in making decision, as the compass of industry, since Think Tank has strong ability of research and participating in politic, thus Think Tank is the intelligence gathering, communication and application platform, it is the intelligent output platform of experts in various industries, and is also the intelligence platform of intelligent and capital.

The development level of Think Tank has become the important component of country's "soft power", since the Third Plenary Session of the Eighteenth Central Committee of Party, nation and government appeal to construct the new think tank with Chinese characteristics, so as to improve national governance system and governance capacity building, then announce Chinese voice in international stage. Under this background, new colleges and universities Think Tank ceremoniously emerges with unprecedented posture, thus the colleges and universities Think Tank construction obtains more and more attentions.

Colleges and universities Think Tank is the organization belongs to university that is engaged in policy research and decision-making consultation, this kind of Think Tank is constructed by university independently or with the support of other organizations and groups. Most of the researchers are the scholars in various disciplines of university or the researchers employed from other universities or research institutes, the service objects and research topics are also very wide. The advance of colleges and universities Think Tank is that, gathering high level talents, leading the disciplines with strong comprehensive nature, rich data and unobstructed information, relaxed academic research atmosphere, etc. these advances can often make the colleges and universities Think Tank generate innovative ideas, methods, results and policy recommendations.

\section{Development course and current situation of colleges and universities think tank abroad}

Think Tank in the modern sense is originated in America during the Second World War, later, it refers to research 
institutions that regard policy research as own duty, and affecting public decision-making and public opinion as purpose in general. World famous Think Tanks include America's Rand Corporation, America's Stanford International Consultative Institution, Hoover Institution, Rockefeller Foundation, International Institute for Applied Systems Analysis, British Royal Society, Japan's Nomura Institute of Research and Germany Industrial Equipment Business Corporation, etc. According to the definition of Frank Koelb Mo who is the founder of international famous Think Tank-Rand Corporation, Think Tank is a 'strategic thinking center' that dares to transcend all existing wisdom, dares to challenge and defy existing authority, it is a Think Tank specializing in study of soft science.

It has nearly hundred years of history since the foundation of first American Think Tank. It is not only a symbol of America's soft power, and also provides strong support for countries to make scientific decisions. For a long time, university research institutions in America not only pay attention to talent cultivation and academic research, and also bear 'Think Tank' national heavy responsibility-directly serving for the needs of international strategy through academic research [1].

As the development of America's economy, science and technology and so on various aspects, the development of colleges and universities Think Tank is more and more rapidly, all the industries of society pay more attention to it. Before the 1970s, universities had been playing the function of country's main Think Tank, then as the specialization of country's decision-making consulting services, professional Think Tank generated and selectively replaced part of work of colleges and universities Think Tank, this made its Think Tank dominant position gradually weaken. But it is still an important part of Think Tank, and constitutes 'three-inhand' of American Think Tank with official Think Tank and independent Think Tank [2]. For example, Hoover Institution in Stanford University, Fairbank Center for East Asian Studies in Harvard University, East Asian Institute in Columbia University and Media Lab in Massachusetts Institute of Technology, etc. are current universities Think Tanks with important international influence. In 2006, a famous Ivy League university Princeton University in America published a national security report entitled Princeton Project, the report attracted great attention of international community, and played an important role in Obama Administration's foreign policy making afterwards. This undoubtedly expresses colleges and universities Think Tank's position in American development. Under America's highly value and developing, among current big three Think Tanks in America, they account for more than $50 \%$ of dependency degree on colleges and universities Think Tank in all aspects. At the same time, American government invests more and more in colleges and universities Think Tank.

The development of Think Tank in America comes from support from government, the people and universities three aspects. According to the Global Think Tank Report 2014 report [3] continuously published by America's University of Pennsylvania in 'Think Tank and Civil Social Programs' on January 22, 2015, nowadays, there are 6681 Think Tanks worldwide, including 1830 in America and 429 in China, they are two countries with the largest number of Think Tanks around the world. America's Brookings Institution, British Royal Institute for International Affairs, America's Carnegie Endowment for International Peace, America's Center for Strategic and International Studies, Belgium's Think Tank Bruegel, Sweden's Stockholm International Peace Research Institute, Rand Corporation, America's Council on Foreign Relations, British International Institute for Strategic Studies and America's Woodrow Wilson International Center respectively rank the top ten in world's top-level Think Tanks. In China, a total of seven Think Tanks enter into 'top 150 of world's top-level Think Tanks', respectively are Chinese Academy of Social Sciences, China Institute of International Studies, China Institutes of Contemporary International Relations, Development Research Center of the State Council, Institute of International and Strategic Studies of Peking University, Shanghai Institutes for International Studies and Chongyang Institute for Financial Studies, Renmin University of China. Compared with last year, Chongyang Institute for Financial Studies, Renmin University of China is a newly increased one. Among them, there are still only two universities Think Tanks [4].

For any Idea Tank, 'quality, independence and influence' are core values that it must conform to, the reasons why Idea Tanks in American universities can have strong influence on public policy and public opinion, are mainly because:

Firstly, the think Tanks in colleges and universities have strong specialty. Think Tank in every university will have its own adept field of study, this is the so-called 'specializing in', and it has set up a certain brand and has important influence on areas of specialization compared with well-known Think Tanks.

Secondly, the perfect and scientific management operation mechanism of Think Tank in colleges and universities ensures its innovation ability and independence; based on independence of scientific research, scientific nature of management, diversification and flexibility of talent cultivation and management model, Think Tanks abroad make them become more neutral in terms of research results and policy suggestions, good reputation and strong strength also make their research achievement transformation be more smooth so as to exert its influence.

Thirdly, the strong social demand and all-around thought spread mechanism ensure the maximization of its influence. Think Tank researchers in American universities are more diversified, most are scholars with professional background and doctoral degree, part of them are former government officials, and there are still senior media practitioners, diversified staff composition ensures close combination of Think Tank research results and social practice, and also ensures the possibility of transformation between thought study and political practice [5].

\section{Foreign think tank's important role}




\subsection{Inspire thought for a variety of policy schemes and suggestions}

The most fundamental task of public decision-making Think Tank is to provide professional advisory opinions and solutions according to decision-making demands, general products include strategic decision report, prospective studies, monographic study report, survey report and information collection analysis, etc. The essence of these services is to provide real information and ideas with reference value so as to make decisionmakers more accurately, systematically and deeply understand objective fact and then more scientifically and reasonably make decisions.

Compared with other research institutions, in the case of mutual combination of talent cultivation and disciplinary research, research institutions in universities are more easily to inspire thinking and create knowledge so as to produce creative thought achievements and policies, and then put forward new ideas and views for reference of policy makers [6].

\subsection{Cultivate talents, affect government public decision-making through talent flow}

The connection between Think Tank of foreign universities and government has various channels. In addition to researchers' regular contact with decisionmaking departments or inviting of government officials to give speeches in Think Tank, more is flow between staff. 'Revolving Door' mechanism is the most distinctive phenomenon in American Think Tank, namely realizing mutual flow between scholars and officials. 'Revolving Door' in American Think Tank makes Think Tank effectively combine with politics, this not only makes American politics maintain vitality and effectiveness, and also makes Think Tank become harbor which cultivates and reserves talents for government [7]. But foreign toplevel Think Tanks also stipulate that it is disallowed that current officials participate in research in principle, and emphasize that 'it must be avoided to get involved in political debates which have nothing to do with study itself', and maintain the purpose of 'not serving for any individual or power groups'. Think Tank experience abroad shows that maintaining objectivity and independence of research work, and maintaining close ties with government are complementary.

\subsection{Educate the masses, guide government and society to reach a consensus so as to promote public policy-making}

You are free to use colour illustrations for the online version of the proceedings but any print version will be printed in black and white unless special arrangements have been made with the conference organiser. Please check with the conference organiser whether or not this is the case. If the print version will be black and white only, you should check your figure captions carefully and remove any reference to colour in the illustration and text. In addition, some colour figures will degrade or suffer loss of information when converted to black and white, and this should be taken into account when preparing them. Think Tank has numerous influencing channels for public opinion, generally including the several following ways: one is to participate in government policy consultation, Think Tank members' statement tends to have important reference effect by virtue of in-depth study of professional field. The second is to release policy reports, publish related policy research reports, works and journals, etc. as reference publications of government officials and researchers. The third is to give an interview and make comments in mainstream media, it is a kind of two-way dependence relationship between Think Tank and media, and this makes ideas of Think Tank be promoted. The fourth is to organize various BBS, lectures and training classes, these projects are usually faced with all industries of government and society, they not only have enlightening effect and also are helpful for Think Tank to strengthen the establishment of contacts with government and all the industries.

\subsection{Track implementation effect of evaluation policy and feedback public decision-making}

As evaluator of policy, Think Tank tracks policy implementation, analyzes problems, predicts consequences and proposes solutions, this has positive significance in government's understanding of policy implementation and effect. First of all, Think Tank's evaluation on policy effect can go beyond limited understanding of a few policy makers, it independently and objectively evaluates policy, integrates attitudes and tendency of various aspects of society toward policy, timely adjusts and supplements policies, and effectively improves policy goals. Secondly, Think Tank's participation of policy evaluation and perfection is conducive to resolving contradiction between interested parties, reflecting fairness and impartiality of policy, and promoting scientification and democratization of government decision-making.

\section{Foreign think tanks' reference role in China's construction of colleges and universities think tanks}

As an important content of promoting the modernization of national governance system and governance ability, Think Tank construction needs to use other countries' mature experience for reference, and also needs to use Chinese wisdom of ruling state and dealing with politics in the history of thousands of years, 'take history as a mirror, make the past serve the present', innovatively develop new colleges and universities Think Tank with Chinese characteristics and international influence. As a knowledge-intensive organization, core competitiveness of colleges and universities Think Tank is intellectual capital. Only to practically improve colleges and universities Think Tank's core competitive advantage, institutional guarantee, talent resources and communication capacity, can China's colleges and universities Think Tank truly become one of the sources 
of power of national rising and truly push China move towards Think Tank power from Think Tank giant.

\subsection{Colleges and universities Think Tank is talent gathering highland, and main force of unique and innovative ideas}

Think Tank development cannot be separated from talent gathering, while colleges and universities have always been places that talents gather, at the same time, colleges and universities are places for cultivating talents, they not only open various majors and gather all kinds of talents, directions and specialties of subject majors in universities specialize in different things, high-level talents have obvious advantages. With the development of informatization, talent requirements are more urgent, the gathering of Think Tank talents in colleges and universities can't be ignored.

As an 'Idea Tank', Think Tank's characteristic is thought gathering. Colleges and universities are just a necessary path of imparting ideological knowledge, faced with good environmental atmosphere and rich foundation of teachers, development of thought must be boundless. In terms of special social status of colleges and universities, their ideas have certain differences with society. Ideological differences often bring new breakthrough, so colleges and universities Think Tank plays an important role in economic and social development $[8,9]$.

\subsection{Practice national requirements, actively construct characteristic colleges and universities Think Tank, and pay attention to the combination of government and universities.}

As huge impact brought by foreign Think Tank, China constantly strengthens efforts in construction of Think Tank. Since policy summary in the Sixth Plenary Session of the Seventeenth Central Committee of Party, Chinese government continuously strengthens efforts in Think Tank construction. Under this policy environment, the construction of colleges and universities Think Tank is also placed on the agenda, faced with numerous policy requirements, government must thoroughly practice national policy requirements and implement various national indicators. At the same time, it must actively construct colleges and universities Think Tank with project characteristics, and offer policy support and encouragement for construction of colleges and universities Think Tank. It should also offer moderate aid for the development and construction of colleges and universities Think Tank, at the same time, it can take measures of the combination of government and universities to seek for mutual development in mutual cooperation [10]. At the same time, it should pay attention to achievement construction of colleges and universities Think Tank, government interior and its development must be in harmony and hand in hand.

\subsection{Take specialized Think Tank as breakthrough to cultivate a batch of new colleges and universities Think Tanks}

New Think Tank with Chinese characteristics should seriously grasp product construction, product of Think Tank is thought, really good thought is necessary. World famous Think Tank development experience shows that selecting strategic and forward-looking major issues for preceding study tends to get immeasurable achievement effect. To enhance China Think Tank' core competitiveness, new universities Think Tank with characteristics must clearly find its own positioning, deeply makes prospective study faced with significant practical issues, long-term issues and strategic issues, and systematically puts forward constructive and operational policy suggestions. Colleges and universities Think Tank must start from intellectual products and focus on the improvement of research quality, including whether issues are accurate, whether proofs are rigorous and whether arguments are powerful, hereby creating a batch of high-end international leading Think Tanks with strong competitive power and high professional level [11].

\subsection{Provide high quality thought products, comprehensively upgrade Think Tank's influence}

Constructing colleges and universities Think Tank with Chinese characteristics, the first is to strengthen Think Tank cultural construction. Based on neutrality, scientific nature and constructive nature, we should stick to Chinese cultural characteristics, adhere to 'seeking truth from fact, basing on the tradition and making innovations', regard interests of the state and people as own duty, and have the courage to pioneer and innovate. Secondly, Think Tank itself should also expand academic, policy, social and international big four influences. In order to expand academic influence, the Chinese Think Tank in university should publish high level academic papers in the famous academic publications. In order to expand policy influence, Think Tank should strengthen study of forward-looking, reserved and strategic issues, obtain more thoughtful policy thinking and innovative research results, and build an information bridge between academic circle and decision-making circle so as to expand Think Tank's influence on high-level decisionmaking $[12,13]$. In order to expand social influence, Think Tank should actively cooperate with mainstream media and fully propaganda valuable research results so as to influence public opinion and lead social ideological trend. In order to expand international influence, Think Tank should represent Chinese academic frontiers and academic schools to take the initiative to participate in global cooperation and competition of Think Tank, and make efforts to expand China's international discourse right and influence.

4.5 Insist on open operation mode of Think Tank and comprehensively upgrade global influence 
Take advantage of global and international vision to plan the development of Think Tank. Today's world is undergoing profound and complicated changes, global cooperation expands to be multilevel and all-dimensional, as first-class Think Tank, if it wants to seize this opportunity and challenge, and directly respond to new situations, new problems and solutions triggered by integration of world economy, it must strengthen global consciousness of Think Tank, focus on studies of major issues and improve China's ability in dealing with international affairs $[14,15]$. At the same time, it should strengthen international exchanges between Think Tanks, energetically develop a variety of long-term or short-term international topic cooperation, and timely exchange understandings and viewpoints. It should strengthen international platform construction of Think Tank, further play the role of Global Think Tank Summit established by domestic Think Tank, create it as an international Think Tank exchange platform with important influence, and make it become famous brand of showing China's soft power.

\section{Conclusion}

Think Tank is the important sign of country's "soft power", Chinese colleges and universities Think Tank has the necessary condition to develop into the big country idea tank with international influence power. This paper analyzes the development course and advanced experience of top-level Think Tank in America and other countries, based on this, it puts forward that Chinese colleges and universities Think Tank should aim at the national strategic needs, play the advantages of talents gathering and main innovation force, insist on opening, and set constructing professional colleges and universities Think Tank as the breakthrough point, thus produce strategic consulting research results with high quality, then construct and train cultivate a series of new colleges and universities Think Tank.

\section{Acknowledgements}

Thank you for the support of strategic consulting research project of Chinese Academy of Engineering.

\section{References}

1. Stella Ladi. Think Tanks and Policy Advice in the US: Academics, Advisors, and Advocates.Public Administration. 87,1 (2009)
2. LiLi W.The development course and challenges facing of American Think Tanks[J].Red Flag Manuscript. 4:33-36 (2009)

3. James G. McGann. 2014 Global Go To Think Tank Index Report. The University of Pennsylvania. 1 (2015)

4. Think Tank Research Center of SASS. An Empirical Research on the Influence of Chinese Think Tanks and Policy Advices[J].Journal of Social Sciences. 4:4-21 (2014)

5. Wang L. International Experience and Its Prospect of Think-tanks in University $[\mathrm{J}]$. Chongqing Social Sciences. 8:106-109 (2012)

6. Sun Z, Zhang Z. On the Development of Think Tank: Based on the Content Analysis of its Academic Definitions[J]. Journal of Intelligence. 1,1 (2011)

7. Research Team on Strengthening Studies on the Building of New-Type Think Tanks with Chinese Characteristics, CCIEE . Building of New-Type Think Tanks with Chinese Characteristics: Present Situation,Problems, and Countermeasures[J]. Globalization.2:107-119(2015)

8. AnGang H. Building a new think tank with Chinese characteristics $[\mathrm{J}]$. Tsinghua Journal of Education. 5: 1-4 (2013)

9. Angang H. Building New Think Tanks with Chinese Features: Practice and Summary [J]. The Journal of Shanghai Administration Institute.25:4-11 (2014)

10. YaMeng Z.The construction method exploration of University Think-tanks influence[J]. Speed Reading.8:292 (2015)

11. ZhenQiang G. Attribute Characteristics of Local University Think-tank and Its Development Strategies $[\mathrm{J}]$. Higher Education Development and Evaluation. 3:37-43 (2014)

12. Li W.Think about University Think Tanks construction[J]. Science \& Technology Information. 27:200-201 (2013)

13. XiaoHu Xu, Qi Chen. Development Process and Prospect of Think Tank [J]. Forum on Science and Technology in China. 7:63-68 (2012)

14. Wei Z, Chen G. The Current Situation of the Construction of Chinese New Think Tanks and the Approaches of Improvement[J]. Education Science. 3:66-70 (2014)

15. Yang J, Chen Y. Reasearch on the construction of University think-tank under theory of Cooperative Innovation[J]. Science \& Technology Progress \& Policy. 7:7-11 (2015) 